\title{
Spatio-temporal variability of temperature and chlorophyll-a concentration of sea surface in Bali Strait, Indonesia
}

\author{
ADI WIJAYA ${ }^{1,2, v}$, UMI ZAKIYAH ${ }^{3}$, ABU BAKAR SAMBAH ${ }^{3}$, DADUK SETYOHADI ${ }^{3, v \vee}$ \\ ${ }^{1}$ Doctoral Programs in Fisheries Science and Marine, Faculty of Fisheries and Marine Science, Universitas Brawijaya. Jl. Veteran, Malang 65145, \\ East Java, Indonesia. Tel.: +62-341-553512. Fax.: +62-341-557837, "email adi.wijaya @kkp.go.id \\ ${ }_{2}^{2}$ Institute for Marine Research and Observation, Ministry of Marine Affair and Fisheries. Jl. Baru, Perancak, Negara, Jembrana 82218, Bali, Indonesia \\ ${ }^{3}$ Faculty of Fisheries and Marine Science, Universitas Brawijaya. Jl. Veteran, Malang 65145, East Java, Indonesia. Tel.: +62-341-553512. \\ Fax.: +62-341-557837, v"email: daduks@ub.ac.id
}

Manuscript received: 1 September 2020. Revision accepted: 19 October 2020.

\begin{abstract}
Wijaya A, Zakiyah U, Sambah AB, Setyohadi D. 2020. Spatio-temporal variability of temperature and chlorophyll-a concentration of sea surface in Bali Strait, Indonesia. Biodiversitas 21: 5283-5290. The Bali Strait is influenced by seasonal and interannual systems. El Nino-Southern Oscillation (ENSO) and Indian Ocean Dipole (IOD) are climate variabilities that affect water conditions. The knowledge about influence of ENSO and IOD variations on the fertility of waters in the Bali Strait is still lacking. The purpose of this study was to determine the effect of seasonal and inter-annual variability on the variability of Sea Surface Temperature (SST) and Sea Surface Chlorophyll- $a$ (SSC) in the Bali Strait. This study applied SST and SSC data collected from the Aqua/Terra MODIS satellite, as well as the ENSO and IOD indices during March 2000-December 2019. The results described that the effect of ENSO on SST and SSC was low and IOD on SST and SSC was quite high. The effect was quite high between IOD and SST anomaly of-0.401. Seasonal variations indicate the abundance of high SSC and low SST in the southeast monsoon (JJA) which characterizes upwelling. Meanwhile, in the northwest monsoon (DJF), SSC was low and SST was high which characterizes downwelling. This condition cannot separate from the monsoonal process that occurred in the Bali Strait. The inter-annual variation showed that in the strong El Nino period and IOD (+) triggers a negative SST anomaly and a positive SSC results in strong upwelling, while in the strong La Nina period and strong IOD (-) triggers a positive SST anomaly and a negative SSC results in downwelling. The inter-annual variability of SSC influenced by IOD rather than ENSO. This condition indicates that the ENSO/IOD event changes the period of SSC concentration.
\end{abstract}

Keywords: Anomaly analysis, El Nino-Southern Oscillation, Indian Ocean Dipole, inter-annual variation, seasonal variation

\section{INTRODUCTION}

The dynamics of marine waters in Indonesia influenced by the diversity of ocean and atmospheric variability, with various phenomena both spatially and temporally. Phenomena that have cycles of diversity include the monsoonal system, Indonesia Through Flow (ITF), El Nino-Southern Oscillation (ENSO), Indian Ocean Dipole (IOD), and Madden Julian Oscillation (MJO (Qu et al. 2005; Susanto et al. 2006; Ratnawati et al. 2016). The seasonal climate variations are formed as a result of the monsoon system Australian to Asia, namely the southeast monsoon (April to October) and northwest monsoon (October to April) the high-low effect on the surfaces layer of the primary productivity (Susanto et al. 2001; Susanto and Marra 2005; Susanto et al. 2006; Gordon et al. 2010). ITF is the transport of water masses from the Pacific Ocean to the Indian Ocean across Indonesian waters, has an important role in the health of marine ecosystems, and is part of the global thermohaline conveyor belt (Ffield and Gordon 1996; Gordon 2005). The ITF shows annual and interannual variations related to the monsoon and ENSO variations, where the ITF in the southeast monsoon is higher than in the northeast monsoon (Ffield and Gordon 1996; Gondon et al. 2010; Sprintall and Revelard 2014).
ENSO as an event of the ocean and atmosphere interactions that produce climatic variations in the tropical Pacific Ocean (Muhammad et al. 2017). Meanwhile, the IOD phenomenon is an event from the interaction of the ocean and the atmosphere in the tropical Indian Ocean, which has a strong impact on the Indian Ocean region (Saji et al. 1999; Yang et al. 2019).

The Bali Strait, which is located between the islands of Java and Bali, connects the Bali Sea to the Indian Ocean and vice versa (Sartimbul et al. 2010; Berlianty and Yanagi 2011). The shallow bathymetry of the Bali Strait in the middle, narrow and steep in the south and faces directly to the Indian Ocean, resulting in high surface currents, both in and out of water (Berlianty and Yanagi 2011). The speed of outflow and entry in the Bali Strait makes the exchange of water masses in these waters more dynamic. The dynamics of waters in the Bali Strait are indirectly affected by the dynamics of waters in the Indian Ocean on intra-annual time scales such as monsoonal, IOD, and ENSO (Iskandar et al. 2009; Sartimbul et al. 2010; Ningsih et al. 2013; Gaol et al. 2014; Sukresno et al. 2018).

During the southeast monsoon (April to October), the waters of the Bali Strait experience an increase in primary productivity, this condition occurs due to the encouragement of southeast winds from Australia which 
produces upwelling, bringing cooler water with high concentrations of nutrient to the surface along the southern coasts of Java and Sumatra. (Susanto et al. 2001; Susanto and Marra 2005; Susanto et al. 2006). The upwelling process occurs due to the Ekman pump process where there is filling of the void in the surface water along the coast by the water mass inside which results in an exchange of water masses from carrying a layer that is rich in nutrients and cold temperatures to the surface layer. (Hendiarti et al. 2004; Qu et al. 2005; Ningsih et al. 2013). The influence of the monsoon, ENSO, and IOD that occurs strongly affects the condition of the Bali Strait waters in both space and time. Many studies on aquatic environmental factors, both physical, biological, and chemical parameters of water of the Bali Strait as well as their relation to the potential of fishery resources have carried out. In the study pertaining to fishing activities of Sardinella lemuru, it was known that fishing is carried out in conditions with a Sea Surface Temperature (SST) ranging between $25-26^{\circ} \mathrm{C}$, and a Surface Chlorophyll- $a$ Concentration (SSC) of 0.25-0.65 $\mathrm{mg} \mathrm{m}^{3}$ (Susilo 2015; Susilo and Wibawa 2016; Pertami et al. 2019). These two parameters of the aquatic environment are important factors in estimating potential fishing areas, especially pelagic fish. Furthermore, the dynamics of aquatic environmental parameters indirectly influenced by global phenomena, such as IOD and ENSO. The IOD and ENSO phenomena affect the high and low catch of Sardinella lemuru in the Bali Strait. The high catch of Sardinella lemuru occurs when El Nino is strong and IOD is positive, namely during 2006 and early 2007 (Sartimbul et al. 2010; Sambah et al. 2013).
During the periods of the monsoon phenomenon, ENSO and IOD also have an impact on the intensity of upwelling that occurs both under normal and anomalous conditions. This causes an increase or decrease in chlorophyll- $a$ concentration and sea surface temperature and affects the production of the catch of Sardinella lemuru in the Bali Strait. The study of the spatial-temporal variation of oceanographic parameters on global phenomena is important to analyze the dynamics of the fish catch and identification of potential fishing grounds. The ultimate goal is sustainable fisheries resource management. This study aims to analyze the spatial-temporal variations of SST and SSC, and to determine its relationship to the climate variations (ENSO and IOD) in the Bali Strait.

\section{MATERIALS AND METHODS}

\section{Study area}

Current study was conducted in the waters of the Bali Strait, with the boundaries of the study area between coordinates of $114.2^{\circ}-115.2^{\circ} \mathrm{W}$ and $8.1^{\circ}-8.9^{\circ} \mathrm{S}$ (Figure 1). Observation was made for a period of nearly 20 years starting from March 2000 to December 2019. The Bali Strait is semi-closed, connecting the water masses from the Bali Sea to the Indian Ocean or vice versa (Berlianty and Yanagi 2011). The area of the Bali Strait is about 2,500 $\mathrm{km}^{2}$ which is shaped like a funnel with shallow topographical conditions in the northern part and deep in the southern part. The average depth is 50 meters and is 2.5 $\mathrm{km}$ wide in the north, while the southern part is $400-1400$ meters deep and $55 \mathrm{~km}$ wide.

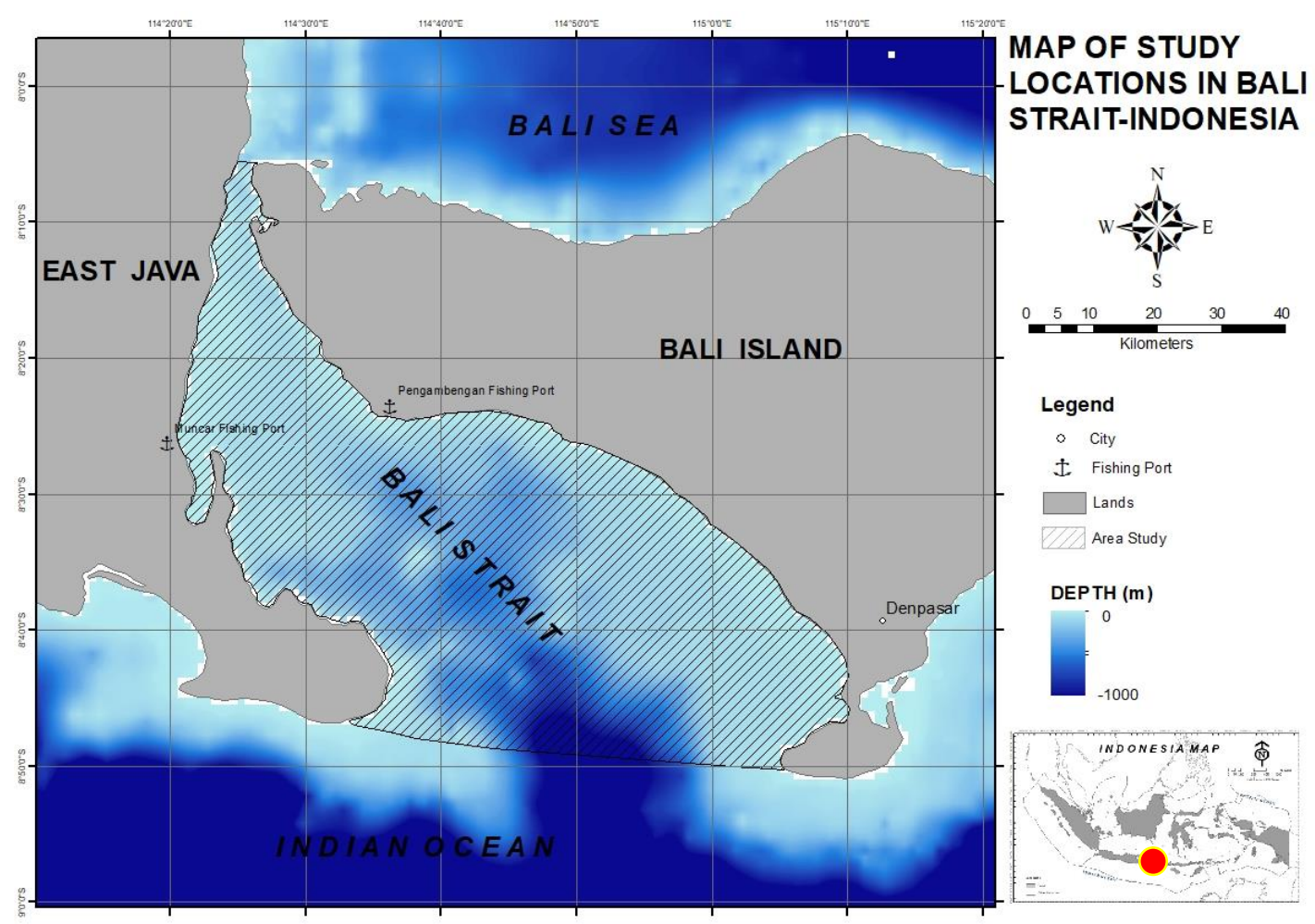

Figure 1. The study area in the Bali Strait, Indonesia 


\section{Dataset}

Sea surface temperature

Sea surface temperature data was obtained from recording Aqua/Terra satellite imagery with the Moderate Resolution Imaging Spectroradiometer (MODIS) sensor, downloaded from https://oceancolor.gsfc.nasa.gov/. The data used were daily SST and is composite to a monthly average at spatial resolution of $1 \mathrm{~km}$ from March 2000 to December 2019. The data analysis system used Linuxbased SeaWiFS Data Analysis System (SeaDAS) version 7.5.3 to process data for the Satellite Aqua/Terra MODIS in the study area. SST was calculated using MODIS Theoretical Basic Documents Algorithm (ATBD MOD 25). Blank data due to the cloud cover, was reconstructed using data interpolation.

\section{Sea surface chlorophyll-a}

Chlorophyll- $a$ data was obtained from Aqua/Terra satellite images with the Moderate Resolution Imaging Spectroradiometer (MODIS) sensor downloaded from https://oceancolor.gsfc.nasa.gov/. The data used were daily chlorophyll- $a$ concentrations and the composite was into a monthly average at spatial resolution of $1 \mathrm{~km}$ from March 2000 to December 2019. The data analysis system used Linux-based SeaWiFS Data Analysis System (SeaDAS) version 7.5.3. Concentration of chlorophyll- $a$ was using the Algorithm Theoretical Basis Documents MODIS (ATBD MOD 19). As with SST data processing, to analyses, blank data on chlorophyll- $a$ due to cloud data, reconstruction of the missing data was carried out using data interpolation using cloud-free climatological data.

\section{El Nino-Southern Oscillation (ENSO) index}

The ENSO index was generated from observations of the ocean and atmosphere interactions in the Trophic Pacific Ocean. ENSO incidence in Indonesian waters and study areas can be identified from the NINO 3.4 area; this index is the mean SST anomaly in the NINO 3.4 region at coordinates $120^{\circ}-170^{\circ} \mathrm{W}$ and $5^{\circ} \mathrm{N}-5^{\circ} \mathrm{S}$ (Susanto and Marra 2005). The threshold was marked at a value of $0.5^{\circ} \mathrm{C}$, above which it was identified as an El Nino period. It was counted as the normal period if the index was between $0.5^{\circ} \mathrm{C}$ to$0.5^{\circ} \mathrm{C}$, and below $-0.5^{\circ} \mathrm{C}$ it was identified as the La Nina period. The ENSO index refers to observations from the NOAA Climate Prediction Center, which can be download on the https://stateoftheocean.osmc.noaa.gov/sur/pac/nino34.php.

\section{Indian Ocean Dipole (IOD) index}

The IOD index was generated from NOAA Climate Prediction Center observations of the ocean and atmosphere interactions in the Trophic Indian Ocean, which can be download from https://stateoftheocean.osmc.noaa.gov/sur/ind/dmi.php. The incidence of IOD in Indonesian territorial waters and study areas can be identified from the western equatorial Indian Ocean $\left(50^{\circ}-70^{\circ} \mathrm{E}\right.$ and $\left.10^{\circ} \mathrm{S}-10^{\circ} \mathrm{N}\right)$ and the southeastern equatorial Indian Ocean $\left(90^{\circ}-110^{\circ} \mathrm{E}\right.$ and $10^{\circ} \mathrm{S}$ $0^{\circ} /$ Equatorial) (Saji et al. 1999). IOD index was taken as positive when the anomaly value of sea surface temperature was positive, while negative IOD period index was considered when the anomaly value of SST was negative. The threshold used to describe positive and negative IOD was taken as $0.4^{\circ} \mathrm{C}$.

\section{Data analysis}

SSC anomaly analysis

As an effort to avoid the erroneous estimation of SSC data from the impact of suspended particles, baseline reflectance, and case- 2 water conditions, valid SSC data from MODIS data in the range $0<\mathrm{SSC}<5 \mathrm{mg} / \mathrm{m}^{3}$ were used. Filtering was carried out on valid SSC data based on the initial analysis of MODIS data so that SSCs in the range of $0-5 \mathrm{mg} / \mathrm{m}^{3}$ were generated. Analysis of variability using anomalies of surface chlorophyll- $a$ parameters using the following approach (Sartimbul et al. 2018):

$$
\text { SSC Anomaly }=\mathrm{Xi}-\mathrm{X}
$$

Where: $\mathrm{Xi}$ is the SSC of the monthly i-month Aqua/Terra MODIS satellite imagery. $X$ is the monthly average of SSC data for the period March 2000-December 2019.

\section{SST anomaly analysis}

To avoid errors due to atmospheric disturbances in SST data, filtering was carried out in the range $23<\mathrm{SST}<33{ }^{\circ} \mathrm{C}$. The temperature range was calibrated on several previous field measurements, where the value was never found to exceed the selected range. Analysis to produce variability using anomalies from SST parameters was carried out with the following equation (Sartimbul et al. 2018):

$$
\text { SST Anomaly }=\text { Yi-Y }
$$

Where: Yi is the SST of the monthly Aqua/Terra MODIS satellite imagery in i-month. $\mathrm{Y}$ is the monthly average of SST data for the period March 2000-December 2019.

\section{Hovmoller diagram}

Hovmoller diagram utilizes spatial analysis of time series data along latitude or longitude. This diagram was used to study the SST and SSC variations in the longitude or latitude coordinates of each month during the observation time in the study area. The data was displayed crosswise against the SST and SSC anomaly data, which represents the numeric pixel value of the time-series data

\section{Relationship analysis}

The relationship between variables was carried out using the correlation technique. This method determines the correlation coefficient using the Pearson correlation equation (Sudjana 1992) as follows:

$$
r=\frac{n \sum X Y-\sum x \sum Y}{\sqrt{\left.\ln \sum X^{2}-\left(\sum X^{2}\right)\right]\left(n \sum Y^{2}-\left(\sum Y^{2}\right)\right]}}
$$


Where:

$\mathrm{R}$ : Pearson correlation coefficient

$\mathrm{X}$ : variable $\mathrm{X}$

$\mathrm{Y}$ : variable $\mathrm{Y}$

$\mathrm{N}$ : number of samples

Classification of the relationship between variables was divide into several criteria based on the resulting correlation coefficient. The correlation coefficient value class consist of very low (0-0.2), low (0.2-0.4), high (0.4$0.7)$ and high (0.7-1.0) relationships (Sharma 2005).

\section{RESULTS AND DISCUSSION}

\section{Inter-annual variations}

Observation of the variation and distribution of SSC from year to year was made using the chlorophyll- $a$ anomaly distribution. The concentration of chlorophyll- $a$ anomaly was calculated as a deviation from the monthly climatological conditions during the period of March 2000December 2019. SSC concentration varies during the period of El Niño/La Niña and the Indian Ocean Dipole (IOD) (Rao and Yamagata 2004; Horii et al. 2008; Mcphaden 2008; Iskandar et al. 2017). The conditions of sea and atmospheric interactions that occurred repeatedly during the observation period as presented in Table 1. This table shows the occurrence of $\mathrm{El} \mathrm{Niño/La} \mathrm{Niña} \mathrm{and}$ positive/negative IOD events from 2000 to 2019 based on the Niño 3.4 Index and Dipole Mode Index (DMI). The Niño 3.4 index was calculated as the mean SST anomaly in the equatorial Pacific Ocean (Mcphaden 2008). Whereas DMI was calculated as the SST gradient between the western tropical Indian Ocean and the southeast tropical Indian Ocean (Saji et al. 1999). The event occurred simultaneously during the period of positive IOD and El Niño in 2006/2007, and 2015/2016. The event also occurred simultaneously in the positive IOD and La Niña in 2007/2008, 2008/2009, and 2011/2012. Meanwhile, negative IOD events occurred simultaneously with La Niña in 2005/2006 and 2010/2011. Based on the Niño 3.4 and IOD indices, $6 \mathrm{El}$ Nino events, $7 \mathrm{La}$ Nina events, 11 positive IOD events, and 2 negative IOD events were found as presented in Table 1.

The distribution of chlorophyll anomalies from 2000 to 2019 is presented in Figure 2.A. Overall, positive anomalies of chlorophyll- $a$ appeared in all waters of the
Bali Strait during El Nino and IOD (+) events. Chlorophyll-concentrations were higher during El Niño events (positive anomaly of chlorophyll- $a$ concentration) than during La Niña events (negative anomaly of chlorophyll- $a$ concentration). In 2015 when a strong El Niño event occurred in the tropical Pacific, chlorophyll- $a$ concentrations were high in almost all of the waters of the Bali Strait (Figure 2.A). The peak of the Chlorophyll anomaly was observed at the end of the El Niño development phase viz. 2002/2003, 2006/2007, 2009/2010, and 2015/2016 occurring in September until the initial peak phase of the events in October-November (Iskandar et al. 2017). The chlorophyll- $a$ concentration decreased in December before the end of the El Niño phase (Figure 2.A). High chlorophyll- $a$ concentrations also occurred during positive IOD events in 2003, 2006, 2010, and 2015. However, chlorophyll- $a$ concentrations were higher and distributed throughout the Bali Strait waters during preIOD in 2003 (Rao et al. 2009) compared to positive IOD events along with an El Niño event in 2006 (Ningsih et al. 2013). When positive IOD events coincided with La Niña events in 2007 and 2011 (Iskandar et al. 2014), Chlorophyll- $a$ concentrations in the Bali Strait increased, particularly during July-August 2007 and AugustSeptember 2011. Opposite situations occurred during La Niña and/or negative IOD events. Chlorophyll- $a$ concentrations were low during strong La Niña and/or negative IOD events in 2010/2011 (Figure 2.A). The mechanism of chlorophyll- $a$ variation in the waters of the Bali Strait was explored on the conditions of spatial and temporal variability of SST during 2000-2019 with an emphasis on El Niño/La Niña events and positive/negative IOD events (Figure 2.B).

It was noticed that changes in SST during the El-Niño and IOD positive events led to change in anomalous patterns indicating that high chlorophyll- $a$ concentrations would be followed by a decrease in negative SST anomalies (Figure 2.B). The analysis shows consistently that low chlorophyll- $a$ concentrations coincide with positive SST. Further, the resulting positive SST anomaly suppressed surface chlorophyll- $a$ concentrations in the Bali Strait, as well as negative SST anomaly was followed by a positive surface chlorophyll anomaly. Two opposing events, a strong La Niña event in 2010/2011 and a strong El Niño event in 2015/2016, resulted in two different ocean and atmospheric conditions in the Bali Strait (Figure 2.C).

Table 1. Classification of El Nino/La Nina and IOD from 2000-2019 based on data NINO 3.4 Index and Dipole Mode Index

\begin{tabular}{llll}
\hline El Nino & La Nina & IOD positive & IOD negative \\
\hline $2002 / 2003,2004 / 2005$, & $2000 / 2001,2005 / 2006,2007 / 2008$, & $2003,2006,2007,2008,2010$, & 2005,2010 \\
$2006 / 2007,2009 / 2010$, & $2008 / 2009,2010 / 2011,2011 / 2012$, & $2011,2012,2015,2017,2018$, & \\
$2015 / 2016,2018 / 2019$ & $2016 / 2017$ & 2019 & \\
\hline
\end{tabular}




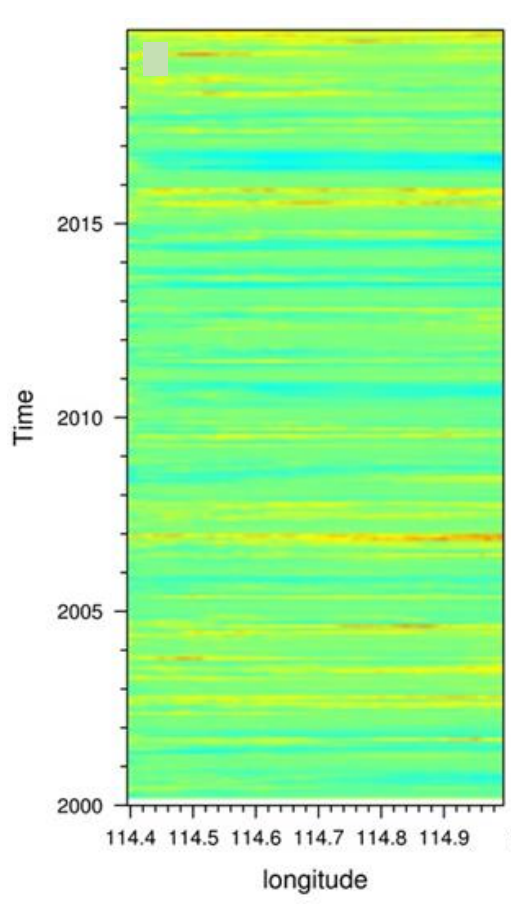

A

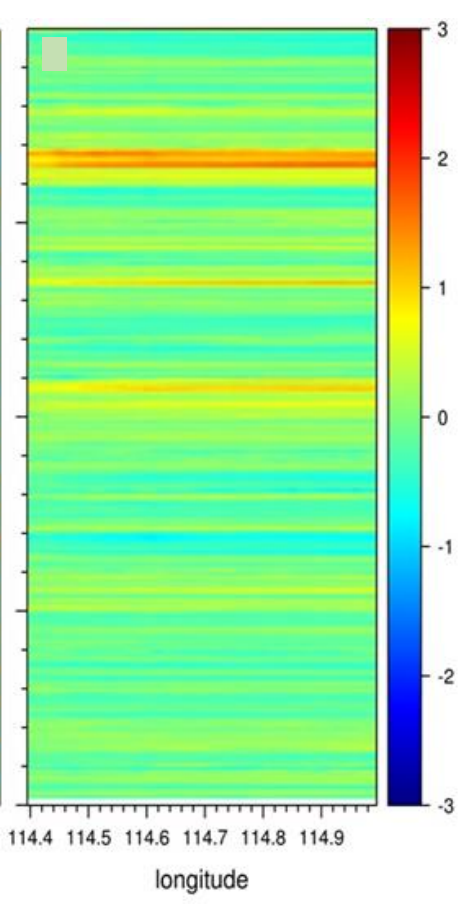

$\mathbf{B}$

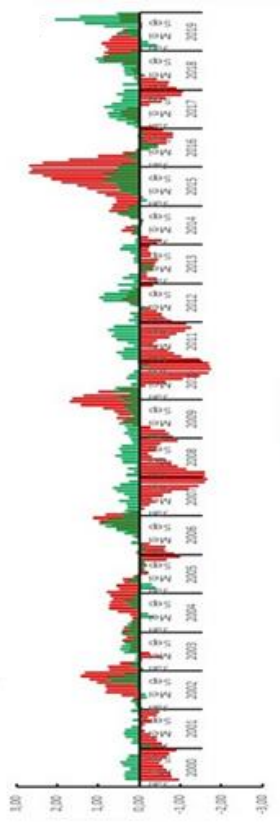

C

Figure 2. Inter-annual variation temporal the distribution of anomalous (A) sea surface chlorophyll- $a$; (B) sea surface temperature in the Bali Strait Indonesia, (C) Nino 3.4 and DM Index

\section{Seasonal variations}

The seasonal variations in the waters of Bali Strait have spatial and temporal variability that is visible from the SSC and SST distributions. Figure 3 shows the climatological data for the distribution of chlorophyll- $a$ in each season. The concentration in the western monsoon period (DJF) was around $0.498 \mathrm{mg} \mathrm{m}^{3}$ and during transition period I (MAM) was $0.80 \mathrm{mg} \mathrm{m}^{3}$. While in the eastern monsoon period (JJA) it increased upto $1.54 \mathrm{mg} \mathrm{m}^{3}$ and in transition II (SON) it reached up to $1.24 \mathrm{mg} \mathrm{m}^{3}$. The chlorophyll- $a$ concentration in the eastern monsoon period (JJA) was high and distributed more widely from the coast than in the SON period. SST monthly climatological data in the JJA period reached $26^{\circ} \mathrm{C}$, which was wide in distribution in the JJA period and began to increase in the SON period (Figure 4). Low SST conditions during the JJA period coincided with the abundance of chlorophyll- $a$ concentrations in the Bali Strait, which is an indication of upwelling.

In the JJA period, the abundance of chlorophyll- $a$ was seen to be higher and distributed extending to the coasts of the islands of Java and Bali. Cooler SST followed this condition to the coasts of Java and Bali Islands. The cold SST conditions brought the nutrient-rich water mass to the surface as indicated by the high chlorophyll- $a$ concentration. The movement of increasing water mass was due to the stratification of layers that have different densities in each layer corresponding to the decrease in temperature with increase in density. Changes in water conditions that resulted in lower SST and increased surface chlorophyll- $a$ concentrations during the JJA period were influenced by strong east winds, which acted as winddriven motion in the upwelling phenomenon during the east monsoon.
On the other hand, when the DJF was in abundance, the chlorophyll- $a$ concentration tended to decrease as well there was increase in SST. This condition identifies the occurrence of downwelling in the Bali Strait. The temporal variation of SSC during the east monsoon shows that the chlorophyll- $a$ concentration was higher than the concentration during the west monsoon (Figure 5). Meanwhile, the temporal variation of SST during the east monsoon was lower than during the west monsoon. It was thus identified that upwelling process alternates with the downwelling process in the Bali Strait.

\section{The relationship between variables}

The relationship between studied variables (Nino 3.4 index, DMI, SSC anomaly, and SST anomaly) were identified with bivariate correlation with the person correlation equation. The results of the analysis show that the variables that have a high enough relationship between DMI and SST anomaly, SSC anomaly with SST anomaly while the values of other variables show low association which is presented in Table 2.

Based on Table 2, it shows that the variability of Chlorophyll anomaly during the incidence of ENSO (El Nino/La Nina) and IOD (+/-) (Figures 2.A and 2.C) has a relationship of- 0.345 and a DMI of- 0.348 . The correlation of ENSO and IOD has a low effect on chlorophyll- $a$ in the waters of the Bali Strait. Meanwhile, the SST anomaly variability during the events of ENSO (El Nino/La Nina) and IOD (+/-) (Figures 2.B and 2.C) has a relationship between ENSO of-0.120 and a DMI of-0.401. The correlation of ENSO has a low effect on SST anomalies and IOD has a high enough effect on SST anomalies in the waters of the Bali Strait. 


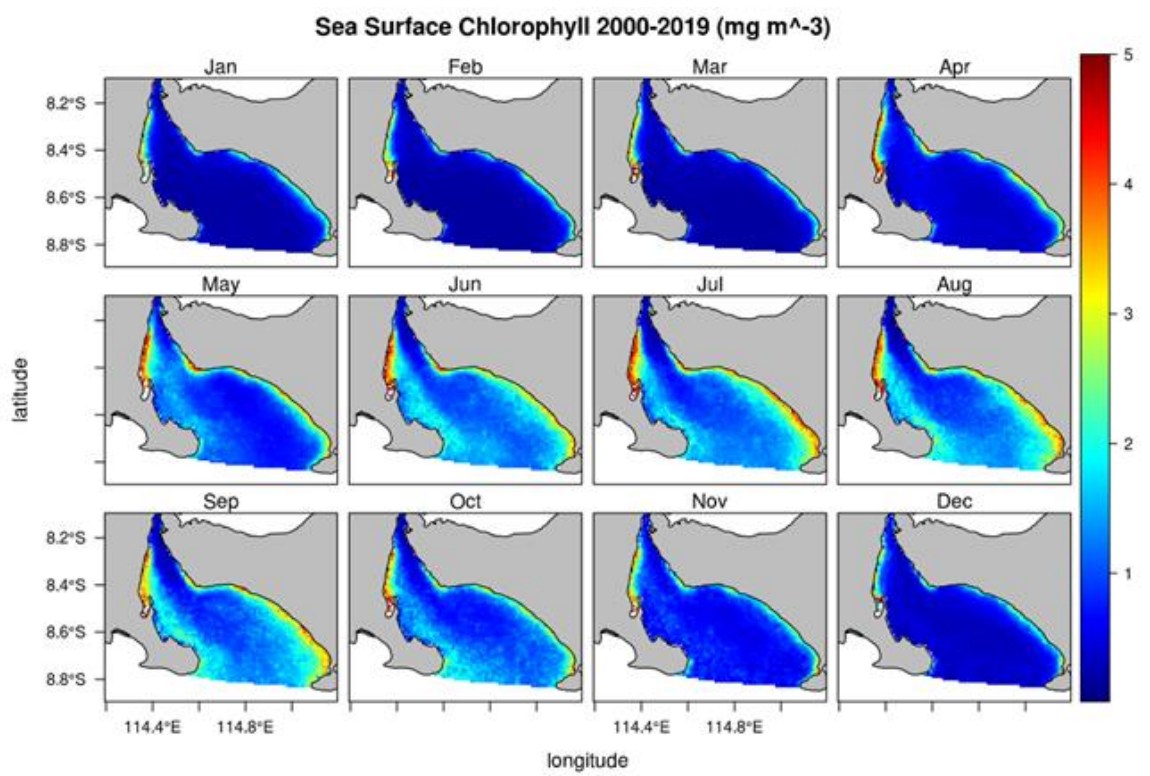

Figure 3. Monthly climatology of sea surface chlorophyll- $a$ in the Bali Strait, Indonesia

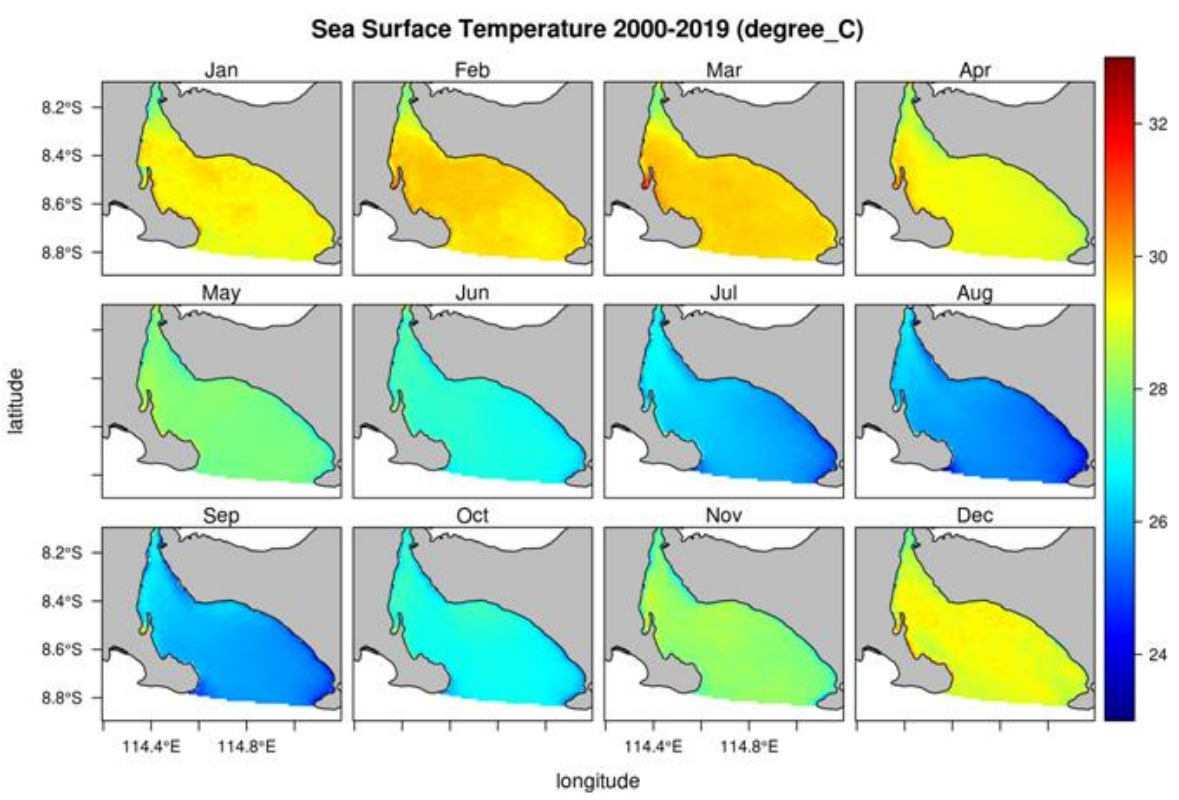

Figure 4. Monthly climatology of sea surface temperature in the Bali Strait, Indonesia

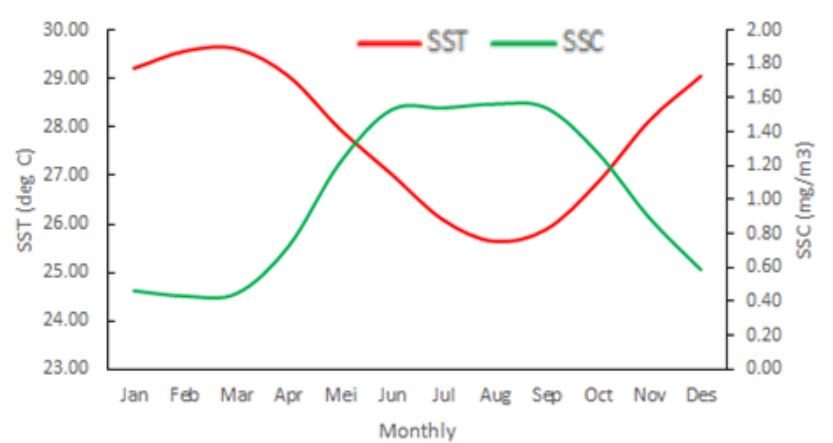

Figure 5. Seasonal variation of sea surface temperature and chlorophyll- $a$ in the Bali Strait, Indonesia
Table 2. Correlation between variables

\begin{tabular}{lcccc}
\hline & Nino 3.4 & DMI & $\begin{array}{c}\text { Anomaly } \\
\text { SST }\end{array}$ & $\begin{array}{c}\text { Anomaly } \\
\text { SSC }\end{array}$ \\
\hline Nino 3.4 & 1 & & & \\
DMI & $0.252^{* *}$ & 1 & & \\
Anomaly SST & -0.120 & $-0.401^{* *}$ & 1 & \\
Anomaly SSC & $0.345^{* *}$ & $0.348^{* *}$ & $-0.592^{* *}$ & 1 \\
& & & & \\
\hline
\end{tabular}

Note: **. Correlation is significant at the 0.01 level 


\section{Discussion}

The Bali Strait is located in the tropics and receives high sunlight so it is beneficial for phytoplankton photosynthesis. In addition, the Bali Strait is semi-closed water and a type of mesotrophic. All of these factors affect the variability of chlorophyll- $a$ concentrations in the Bali Strait. The seasonal and inter-annual variation of chlorophyll- $a$ concentration in the Bali Strait with the help of remote sensing data makes it easy to understand the distribution of chlorophyll- $a$ concentrations in the Bali Strait. Current study carried out with Aqua/Terra MODIS Satellite Data was helpful to identify seasonal and interannual variations in surface chlorophyll- $a$ distribution in the Bali Strait. During the eastern monsoon, chlorophyll- $a$ concentrations are higher throughout the Bali Strait waters. The evolution of chlorophyll- $a$ concentrations begins in June-September and peaks in September due to the east monsoon winds heading for the South Coast of Java Island into the Bali Strait causing subsurface water to be transported offshore. East monsoon currents push offshore water into the center of the Bali Strait, pushing water upward with high surface chlorophyll concentrations. On the other hand, during the western monsoon, the SST anomaly was increased and there was decreased chlorophyll- $a$ concentration in the Bali Strait (Ratnawati et al. 2016). High chlorophyll- $a$ concentrations along the coast were caused by the supply of nutrients from river runoff entering the Bali Strait (Zakiyah et al. 2015).

The intra-annual anomaly variation of surface chlorophyll- $a$ concentration in the Bali Strait, as presented in Figure 2.A, is closely related to ocean and atmospheric conditions that occur in the Indo-Pacific tropical region, namely El Niño/La Niña, and the Indian Ocean region, namely positive/negative IOD events. This study revealed that surface Chlorophyll concentrations were high during El Niño and/or positive IOD events. The occurrence of ENSO and IOD phases gave spatial patterns of Chlorophyll and SST anomalies during ENSO/IOD events from climatological data. During El Niño and positive IOD events in 2006 and 2015, the Bali Strait experienced a negative SST phase. This condition was seen during the initial phase of the evolution of positive IOD from June and increased in October. Whereas in El Nino, the chlorophyll$a$ concentration in the waters was relatively higher and uniform. This condition was reversed during La Niña due to weak winds and high sea surface temperatures, which resulted in decreased chlorophyll- $a$ concentrations. An increase in surface chlorophyll- $a$ concentration occurred during El Nino and/or positive IOD events; this condition was reinforced by the presence of upward Ekman transport induced by seasonal winds (Ratnawati et al. 2016). This situation was reversed during La Niña and/or negative IOD events in 2010. Meanwhile, the warmer SST anomalies in the Bali Strait in La Niña started in June and ended in December. Variations of climate anomalies were rare in 2007 due to positive IOD and La Niña events respectively (Behera et al. 2008). These events suggest that the anomalous evolution of chlorophyll- $a$ concentrations follow a negative SST pattern. In addition, the El Niño ( $\mathrm{La}$ Niña) event changed the increase in concentration of chlorophyll- $a$ and decreased SST in the Bali Strait, and did not change the area of high concentration and decrease in SST. The analysis showed that the inter-annual variability of chlorophyll- $a$ was influenced by the Indian Ocean Dipole rather than by ENSO. These findings suggest that the ENSO/IOD event alters the period of increasing chlorophyll- $a$ concentration.

In conclusion, the variability of SST and chlorophyll- $a$ was related to the incidence of upwelling and downwelling, which was influence by seasonal and inter-annual variability. On a seasonal and inter-annual scale, the intensity of the eastern monsoon increases during $\mathrm{El}$ Nino/IOD (+) periods and weakens during La Nina/IOD (). The effect of ENSO and IOD on SST and chlorophyll- $a$ variability in the waters of the Bali Strait during the El Nino period were strong along with IOD (+) and it caused cold SST and high chlorophyll- $a$ while strong La Nina phenomena along with IOD (-)caused Warm SST and low chlorophyll- $a$. The effect of inter-annual climate variability has a high enough correlation value between IOD and SST. Based on the correlation value, IOD is linked more with SST and Chlorophyll anomalies than ENSO.

\section{ACKNOWLEDGEMENTS}

Thanks go to NASA and IMRO for providing satellite and in situ data for this study. We also thank NASA for providing the "online data system for analysis and visualization" used in this paper. The author also thanks Ms. Frida Sidik, Ph.D., (Associate Expert Researcher from Institute for Marine Research and Observation) for her discussion, suggestions, and input in writing articles. For author contributions, the data were analyzed and put together into a paper by AW, with support from UZ, ABS, and DS.

\section{REFERENCES}

Behera SK, Luo JJ, Yamagata T. 2008. Unusual IOD event of 2007. Geophys Res Lett 35: L14S11. DOI:10.1029/2008GL034122.

Berlianty D, Yanagi T. 2011. Tide and tidal current in the Bali Strait, Indonesia. Mar Res Indones 36 (2): 25-36.

Field A, Gordon AL. 1996. Tidal mixing signatures in the Indonesian seas. J Phys Oceanogr 26 (9): 1924-1937

Gaol JL, Wudianto, Pasaribu BP, Manurung D, Endriani R. 2014. The fluctuation of chlorophyll- $a$ concentration derived from satellite imagery and catch of oily sardine (Sardinella lemuru) in Bali strait. Remote Sens Earth Sci 1: 24-30.

Gordon AL. 2005. Oceanography of the Indonesian seas and their throughflow. Oceanography 18 (4): 14-27.

Gordon AL, Sprintall J, Van Aken HM, Susanto D, Wijffels S, Molcard R, Field A, Pranowo W, Wirasantosa S. 2010. The Indonesian throughflow during 2004-2006 as observed by the INSTANT program. Dyn Atmos Ocean 50 (2): 115-28.

Hendiarti N, Siegel H, Ohde T. 2004. Investigation of different coastal processes in Indonesian waters using SeaWiFS data. Deep-Sea Res Part II: Top Stud Oceanogr 51: 85-97.

Horii T, Hase H, Ueki I, Masumoto Y. 2008. Oceanic precondition and evolution of the 2006 Indian ocean dipole. Geophys Res Lett 35: L03607. DOI:10.1029/2007GL032464.

Iskandar, I, Mardiansyah W, Setiabudidaya D, Poerwono P, Kurniawati N, Saymsuddin F, Nagura M. 2014. Equatorial oceanic waves and the 
evolution of 2007 positive Indian Ocean dipole. Terrestrial Atmos Oceanic 25 (6): 847-856. DOI:10.3319/TAO.2014.08.25.01(Oc).

Iskandar, I, Rao SA, Tozuka T. 2009. Chlorophyll- a bloom along the Southern Coasts of Java and Sumatra during 2006. Int J Remote Sens 30 (3): 663-671.

Iskandar I, Utari PA, Lestari DO, Sari QW, Setiabududaya D, Khakim MYN, Yustian I, Dahlan Z. 2017. Evolution of 2015/2016 El Niño and its impact on Indonesia. AIP Conf Proc 1857: 080001-1-0800015. DOI:10.1063/1.4987095.

Mcphaden MJ. 2008. Evolution of the 2006-2007 El Nino: the role of intraseasonal to interannual time scale dynamics. Adv Geosci 14: 219-230.

Muhammad FR, Kristanto Y, Amanullah IW. 2017. Karakteristik Madden-Julian Oscillation (MJO) ketika El-Nino Southern Oscillation (ENSO). Wahana Fisik 2: 76-99. [Indonesian]

Ningsih NS, Rakhmaputeri N, Harto AB. 2013. Upwelling variability along the southern coast of Bali and in Nusa Tenggara waters. Ocean Sci J 48 (1): 49-57.

Pertami ND, Nurjaya IW, Damar A, Rahardjo MF. 2019. The spatial pattern relationship between SST and chlorophyll- $a$ in Lemuru Bleeker, 1853 catches in Bali strait, Indonesia. IOP Conf Ser: Earth Environ Sci 278: 012058

Qu T, Du Y, Strachan J, Meyers G, Slingo J. 2005. Sea surface temperature and its variability in the Indonesian region. Oceanography 18 (4): 50-61.

Rao SA, Luo JJ, Behera SK, Yamagata T. 2009. Generation and termination of Indian Ocean dipole events in 2003, 2006 and 2007. Clim Dyn 33 (6): 751-767.

Rao SA, Yamagata T. 2004. Abrupt termination of Indian Ocean dipole events in response to intraseasonal disturbances. Geophys Res Lett 31: L19306. DOI:10.1029/2004GL020842

Ratnawati HI, Hidayat R, Bey A, June T. 2016. Upwelling di Laut Banda dan pesisir selatan Jawa serta hubungannya dengan ENSO dan IOD. Omni-Akuatika 12: 119-130. [Indonesian]

Saji NH, Goswami BN, Vinayachandran PN, Yamagata T. 1999. A dipole mode in the tropical Indian ocean. Nature 401 (6751): 360-363.

Sambah AB, Miura F, Kadarisman HP, Sartimbul A. 2013. Remote sensing application for Sardinella lemuru assessment: A case study of the south Waters of Malang Regency, East Java, Indonesia. In: Frouin
RJ, Ebuchi N, Pan D, Saino T. (eds.) Remote Sen Mar Environ II Proc SPIE 8525: 85250 .

Sharma AK. 2005. Text Book of Correlations and Regression. Discovery Publishing House, India.

Sartimbul A, Nakata H, Rohadi E, Yusuf B, Kadarisman HP. 2010. Variations in chlorophyll-a concentration and the impact on Sardinella lemuru catches in Bali strait, Indonesia. Prog Oceanogr 87 (1-4): 168-174.

Sartimbul A, Rohadi E, Ali MF, Khaidar Z. 2018. Anomaly technique for expression the Indian ocean dipole in South Java sea. Intl J Eng Technol 7 (4.44): 28-30.

Sprintall J, Revelard A. 2014. The Indonesian throughflow response to Indo-Pacific climate variability. J Geophys Res Ocean 119 (2): 28432859

Sudjana MM. 1992. Metode Statistik. Tarsito, Bandung. [Indonesian]

Sukresno B, Jatisworo D, Kusuma DW. 2018. Analisis multilayer variabilitas upwelling di perairan Selatan Jawa. J Kelautan Nasional 13: 15-25. [Indonesian]

Susanto RD, Gordon AL, Zheng Q. 2001. Upwelling along the coasts of Java and Sumatra and its relation to ENSO. Geophys Res Lett 28 (8): 1599-1602.

Susanto, RD, Marra J. 2005. Effect of the 1997/98 El Nino on chlorophyll- $a$ variability along the Southern Coasts of Java and Sumatra. Oceanography 18 (4): 124-127.

Susanto RD, Moore TSII, Marra J. 2006. Ocean color variability in the Indonesian Seas during the seaWiFS era. Geochem Geophys Geosyst 7 (5): 1-16.

Susilo E. 2015. Variabilitas faktor lingkungan pada habitat ikan lemuru di Selat Bali menggunakan data satelit oseanografi dan pengukuran insitu. Omni-Akuatika 14: 13-22. [Indonesian]

Susilo E, Wibawa TA. 2016. Utilization of satellite oceanography data to predict lemuru fishing ground-based on food chain and statistical GAM approach. J Kelautan Nasional 11: 77-87. [Indonesian]

Yang G, Zhao X, Li Y, Liu L, Wang F, Yu W. 2019. Chlorophyll variability induced by mesoscale eddies in the southeastern tropical Indian ocean. J Mar Syst 199: 103209.

Zakiyah U, Herawati EY, Kusriani K. 2015. Assessment of trophic status in Bali strait. Res J Life Sci 2 (3): 189-198. 